\title{
Identity Politics in a Mediatized Religious Environment on Facebook: Yes to Wearing the Cross Whenever and Wherever I Choose
}

\author{
Mona Abdel-Fadil
}

Department of Media and Communication, University of Oslo

mona.abdel-fadil@media.uio.no

\begin{abstract}
The Norwegian Facebook page Yes to Wearing the Cross Whenever and Wherever I Choose was initially created to protest the prohibition of the cross for NRK news anchors. Yet, many of the discussions and audience interactions transpired into heated religio-political debates with strong elements of anti-Muslim, xenophobic, anti-secular, and anti-atheist sentiments. This study aims to contribute to a more nuanced understanding of the interplay between media and religion by providing new insights on the variety of ways in which media audiences may 'add a series of dynamics to conflicts, namely, amplification, framing and performative agency, and co-structuring' and 'perform conflict', as formulated by Hjarvard et al. It is argued that mediatized conflicts with inherent trigger themes, which tug at core religio-political identity issues, also tend to evoke emotional responses, which, in turn, inspire social media users to perform the conflict in ways that multiply the conflict(s).
\end{abstract}

\section{Keywords}

media and religion - media anthropology - mediatized conflict - Islamophobia Facebook debates - politics - social media - Christianity - xenophobia

The cross is forbidden in Norway!

Muslims are to blame!

Immigrants threaten Norwegian culture!

(C) ABDEL-FADIL, 2017 | DOI 10.1163/18748929-01004001

This is an open access article distributed under the terms of the prevailing CC-BY-NC license at the time of publication. 


\section{Preserve Christianity!}

There is no religious freedom in Norway!

To hell with religion!

All religions are equal!

Love thy neighbour.

Media anthropologists tend to favor studying how social media practices are embedded in everyday life and localities over online research. ${ }^{1}$ For instance, the Why We Post project provides highly valuable insights on the similarities and differences in local social media practices across multiple national contexts (Brazil, Chile, China, England, India, Italy, Trinidad, and Turkey). ${ }^{2}$ Some anthropologists are slightly dismissive of the value of studying one interface, special interest groups, or fleeting politically charged moments as they do not deem them as representative of the everyday social media practices of 'most people. ${ }^{3}$ While these are valid inferences, I believe that studying a special interest group at a particularly charged political moment may yield additional insights that add nuance to our understanding of social media users' engagement with religio-political topics.

Intriguingly, several studies conclude that many people harbor a general reluctance to discuss political, religious, or contentious issues in contexts that are perceived as representing a spectrum of political views or with people with whom they radically disagree, a tendency Elisabeth Noelle-Neumann has termed the "spiral of silence." Based on the ethnographic study of social media usage in eight localities across the globe, Daniel Miller and his colleagues argue:

[...] people felt that expressing political views and opinions could result in antagonism or conflict; as a result politics remains invisible and discussion is reserved for private spaces among one's closest friends and family. 5

1 Daniel Miller et al., How the World Changed Social Media (London: UCL Press, 2016); John Postill \& Sarah Pink, "Social Media Ethnography: The Digital Researcher in a Messy Web," Media International Australia 145/1 (2012), 123-134; Sarah Jurkiewicz, "Being a Blogger in Beirut: Production Practices and Modes of Publicness," PhD diss. (Oslo: University of Oslo, 2012).

2 Miller et al., How.

3 Ibid., 144.

4 Quoted in ibid., 145.

5 Ibid., 153 . 
Many people in various corners of the world, seem to reserve politically charged conversations for interactions with people with whom they agree and thus shy away from such conversations in social media. ${ }^{6}$ Surveys conducted in Scandinavia support Miller's findings. ${ }^{7}$ For instance, one survey indicates that Norwegians favor discussing religion and contemporary issues face to face amongst family members and friends rather than online. ${ }^{8}$ Taken together, then, research from a variety of geographical contexts suggests that most people shy away from discussing politics and religion on social media because they want to avoid conflict. One notable exception is engaging with political issues in social media exclusively as a mode of entertainment, through bantering or relishing in scandal. ${ }^{9}$ Miller concludes that "social media was mainly used by ordinary people to 'watch' politics, even as spectators watch a football match, rather than to 'do' politics."10 While this is, indeed, an intriguing finding, it does not necessarily apply to other studies of social media within a different field, methodological approach, or a different set of research queries. For instance, my study is from the outset a study about 'doing politics' and aims to provide a grounded analysis of the ways in which social media users shape mediatized religious conflicts and engage in identity politics.

6 Ibid., 145 and 153-155; CoMRel: Engaging with Conflicts in Mediatized Religious Environments, survey, 2014-2017. http://www.hf.uio.no/imk/english/research/projects/comrel/ (accessed 11 May 2017); Stig Hjarvard, "Politik er farlig på Facebook: Sociale medier er ikke danskernes politiske forsamlingshus [Politics Is Dangerous on Facebook: Social Media Are Not Equivalent to Community Centers for Danes]," 2015. http://www.kommunikationsforum.dk/artikler/Sociale-medier-er-ikke-danskernes-politiske-forsamlingshus (accessed 11 May 2017); Kulturstyrelsen, "Sociale medier brug, interesseområder og debatlyst [Social Media Use, Interests, and the Desire to Debate]," 2015. http://slks.dk/mediernesudvikling-2015/specialrapporter/sociale-medier/ (accessed 11 May 2017).

$7 \quad$ Kulturstyrelsen, "Sociale"; CoMRel.

8 CoMRel.

9 In Miller's assessment, topics pertaining to morality and religion may receive more-or at least more serious—attention from users of social media. Miller et al., How, 152. See also ibid., 147; Estr Pollack, "Personalized Scandalisation: Sensationalising Trivial Conflicts?," in: Mikkel Fugl Eskjær, Stig Hjarvard, \& Mette Mortensen (eds.), The Dynamics of Mediatized Conflicts (New York: Peter Lang, 2015), 93-110; Johanna Sumiala, "Ritual Performance in Mediatized Conflict: The Death of a Princess and a Prime Minister," in: Mikkel Fugl Eskjær, Stig Hjarvard, \& Mette Mortensen (eds.), The Dynamics of Mediatized Conflicts (New York: Peter Lang, 2015), 111-128.

Miller et al., How, 152-153. 
Online research on Facebook and religion has often focused on devotional practices or faith-based content. ${ }^{11}$ Likewise, as Matthew J. Kushin and Kelin Kitchener point out, much of the research on social network sites has been on "networks and their structures, privacy issues, management of friends and online impressions."12 It may well be true that those who discuss politics or religio-politics in social media are statistically few, but their numbers are far from insignificant and their online activity is vast. Some qualitative studies have focused on 'doing politics,' however research on politicized debates on Facebook is still rather scarce. ${ }^{13}$ Whether or not online debates generally contribute to an increase in polarization is disputed. ${ }^{14}$ Certainly, a number of studies illustrate that polarized opinions are frequently expressed in conflicts that play out in social media. ${ }^{15}$ As Kushin and Kitchener argue, debaters on Facebook may engage in both productive and unproductive styles of argumentation. ${ }^{16}$ Several scholars discuss media audiences' selective attention and funneling

11 Paul K. McClure, "Faith and Facebook in a Pluralistic Age: The Effects of Social Networking Sites on the Religious Beliefs of Emerging Adults," Sociological Perspectives 59/4 (2016), 818-834; Martin Slama, "Islamic (Inter)Faces of the Internet: Emerging Socialities and Forms of Piety in Indonesia," research project, 2014-2017. http://www .oeaw.ac.at $/$ isa $/$ index.php?option $=$ com_content $\&$ view $=$ article $\&$ id $=392 \% 3$ Aislamic-in terfaces-of-the-internet\&catid $=41 \% 3$ Asuedostasien-und-inselwelt-im-indischen-ozean \& Itemid=65\&lang=de (accessed 11 May 2017). This also holds true for many other forms of studies of online religion. See, e.g., Lorne L. Dawson \& Douglas E. Cowan, Religion Online: Finding Faith on the Internet (New York: Routledge, 2004); Heidi Campbell, When Religion Meets New Media (New York: Routledge, 2010).

12 Matthew J. Kushin \& Kelin Kitchener, "Getting Political on Social Network Sites: Exploring Political Discourse on Facebook," First Monday 14/11 (2009). http://firstmonday.org/ojs/ index.php/fm/article/view/2645/2350 (accessed 4 December 2015).

13 Kushin \& Kitchener, "Getting”; Miller et al., How.

14 See, e.g., Rune Karlsen, et al., "Echo Chamber and Trench Warfare Dynamics in Online Debates," European Journal of Communication (2017). http://journals.sagepub.com/doi/ full/10.1177/0267323117695734 (accessed 9 May 2017); Kushin \& Kitchener, "Getting."

15 Kushin \& Kitchener, "Getting”; Asmina Michailidou \& Hans-Jörg Trenz, "Mediatized Transnational Conflicts: Online Media and the Politicisation of the European Union in Times of Crisis," in: Mikkel Fugl Eskjær, Stig Hjarvard, \& Mette Mortensen (eds.), The Dynamics of Mediatized Conflicts (New York: Peter Lang, 2015), 51-69; Tine Ustad Figenschou, Kjersti Thorbjørnsrud, \& Anna Grøndahl Larsen, "Mediatized Asylum Conflicts: Human-Interest Framing and Common-Sense Public Morality," in: Mikkel Fugl Eskjær, Stig Hjarvard, \& Mette Mortensen (eds.), The Dynamics of Mediatized Conflicts (New York: Peter Lang, 2015), 129-145.; Alison Anderson, "The Mediatization of Environmental Conflict in the 'Network Society," in: Mikkel Fugl Eskjær, Stig Hjarvard, \& Mette Mortensen (eds.), The Dynamics of Mediatized Conflicts (New York: Peter Lang, 2015), 1-27. 
of information, which may serve to enhance biases and contribute to a more polarized debate. ${ }^{17}$ 'Spiraling argumentation' is often a side effect of the latter. Spiraling arguments are an example of the so-called 'unproductive' styles of argumentation which may contribute to further skewing of debates.

This article seeks to examine the multiple ways in which users of social media play in to the constructions of public religious discourse and identity politics in connection with mediatized conflicts about religion. The study aims to contribute to a more nuanced understanding of the interplay between media and religion through researching a particular European, social, and cultural context. Drawing on rich empirical material from the Norwegian Facebook page Yes to Wearing the Cross Whenever and Wherever I Choose, this article aims to examine and provide new insights on the ways in which media audiences may "add a series of dynamics to conflicts, namely, amplification, framing and performative agency, and co-structuring," as formulated by Stig Hjarvard and his colleagues. ${ }^{18}$ As illustrated in Figure 1, Hjarvard maintains that there are four possible outcomes of mediatized conflicts: (1) reduce or resolve conflicts; (2) generate new conflicts; (3) transform existing conflicts; and (4) intensify or prolong conflicts. ${ }^{19}$

Drawing on Hjarvard's framework, as well as several of the contributions to the edited volume The Dynamics of Mediatized Conflicts, this article seeks to contribute to deepening our knowledge with regards to how social media users enact and perform conflict in ways that intensify, transform, multiply, or resolve the conflict(s). ${ }^{20} \mathrm{~A}$ case in point is the Facebook group Yes to Wearing

17 Marie Gillespie, "Introduction: What Is the Audience and Why Is It Important?," in: Marie Gillespie (ed.), Media Audiences (Berkshire \& New York: Open University Press, 2005), 10-11; Gunn S. Enli, "Gate-keeping in the New Media Age," Javnost: The Public 14/2 (2007), 47-61, at 54-59; Sonia Livingstone, "Media Audiences, Interpreters and Users," in: Marie Gillespie (ed.), Media Audiences (Berkshire \& New York: Open University Press, 2005), 9-50.

18 Stig Hjarvard, Mette Mortensen, \& Mikkel Fugl Eskjær, "Three Dynamics of Mediatized Conflicts," in: Mikkel Fugl Eskjær, Stig Hjarvard, \& Mette Mortensen (eds.), The Dynamics of Mediatized Conflicts (New York: Peter Lang, 2015), 1-27, at 6.

19 Ibid., 11.

20 Stefanie Averbeck-Lietz, Andreas Hepp, \& Rebecca Venema, "Communicative Figurations of Financial Blogging: Deliberative and Moralising Modes of Crisis Communication During the Euro Crisis," in: Mikkel Fugl Eskjær, Stig Hjarvard, \& Mette Mortensen (eds.), The Dynamics of Mediatized Conflicts (New York: Peter Lang, 2015), 71-89; Lilie Chouliaraki, "Mediatized Death in the Post-Arab Spring Conflicts," in: Mikkel Fugl Eskjær, Stig Hjarvard, \& Mette Mortensen (eds.), The Dynamics of Mediatized Conflicts (New York: Peter Lang, 2015), 185-203; Kushin \& Kitchener, “Getting”; Michailidou \& Trenz, 


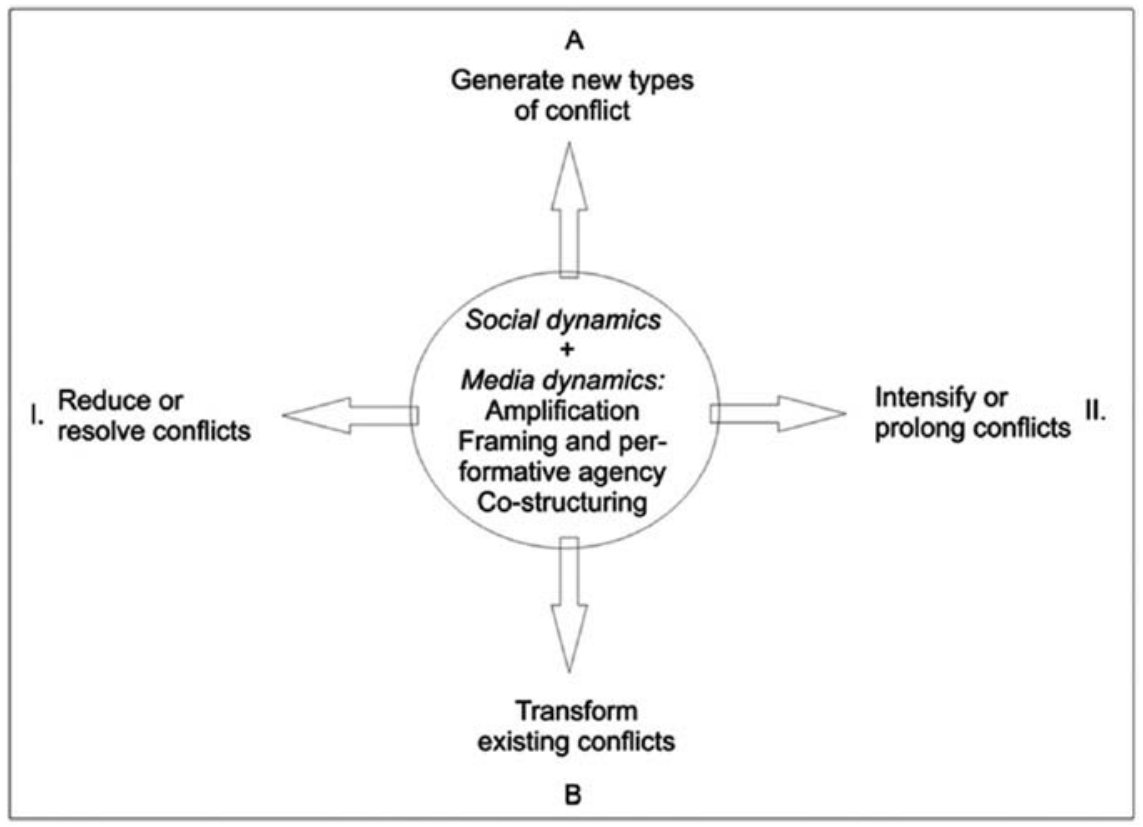

FIGURE 1 The Dynamics of Mediatized Conflicts

the Cross Whenever and Wherever I Choose, which was established at "politically charged moments" in response to an impassioned debate on the visibility of religion on NRK (Norwegian Broadcasting Corporation). ${ }^{21}$ The conflict was sparked by a piece of jewelry worn by a news anchor on TV. The debate about the news anchor's cross-pendant raced across multiple media platforms. The Norwegian Public Broadcasting Council swiftly ruled that wearing a cross in the newsroom was a breach of policy, much to the dissatisfaction of the

"Mediatized"; Figenschou, Thorbjørnsrud, \& Grøndahl Larsen, "Mediatized"; Anderson, "The Mediatization." This study is a subproject of the Scandinavian study CoMRel.

21 The phrase "politically charged moments" — used by Miller et al., How, 145—shares many commonalities with the term "mediatized moment" — as used in Sumiala, "Ritual," 111, as well as the concept "critical moments" — as employed by Terje Colbjørnsen, Colbjørnsen, Terje. "Debating Freedom of Expression in Norwegian Media: Critical Moments, Positions and Arguments." In Boundary Struggles: Contestations of Free Speech in the Norwegian Public Sphere, edited by Arnfinn H. Midtbøen, Kari Steen-Johnsen, and Kjersti Thorbjørnsrud. Oslo: Cappelen Damm Akademisk, 2017. https://www.duo.uio.no/ bitstream/handle/10852/56820/Boundary\%2Bstruggles_published.pdf?sequence $=2$. Though this latter term was originally Boltanski and Thévenot's concept. See Luc Boltanski \& Laurent Thévenot, "The Sociology of Critical Capacity," European Journal of Social Theory 2/3 (1999), 359-377. 
majority of those actively debating on the Facebook page in question. While Yes to Wearing the Cross Whenever and Wherever I Choose was initially created to protest the prohibition of the cross for NRK news anchors, many of the discussions and audience interactions transpired into heated religio-political debates with strong elements of anti-Muslim, xenophobic, anti-secular and anti-atheist sentiments, as some of the introductory quotes (reconstructions) indicate.

Norway is a country with a small population, yet, much like other parts of Europe, tensions are on the rise, with regard to both immigration and Islam. Several surveys indicate that many Norwegians (roughly half the population) perceive Islam as a threat to 'Norwegian culture.'22 Still, as Knut Lundby and Kjersti Thorbjørnsrud point out, only roughly 100,000 of Norway's five million citizens have registered with Muslim communities, meaning the perceived threat of Islam is somewhat inflated. ${ }^{23}$ Yet, as will be illustrated, it certainly leaves a considerable mark on the case in question.

In a European context, 'trigger themes' such as 'immigration,' 'religion,' and 'climate,' are more likely to induce spiraling arguments and the escalation of conflicts and to draw the interest of particular types of audiences. ${ }^{24}$ In addition, I would argue that trigger themes paired with topics that pertain to personal belief systems and identity politics may be particularly well suited to draw out emotive responses, a point to which I will return.

Hjarvard maintains that mediatized conflicts involve particular dynamics such as amplification and co-structuring, which are extensions of performative functions of agency, lending dramaturgy to conflict. If applied to the case of social media, users enact and perform the conflict in multiple ways in order to attract attention. Performative agency then may include the ways in which actors frame the conflict, the repetitive patterns of communication through which they communicate, such as trigger themes and emotional cues. ${ }^{25} \mathrm{I}$ am

\section{CoMRel.}

23 Knut Lundby \& Kjersti Thorbjørnsrud, "Mediatization of Controversy: When the Security Police Went on Facebook," in: Stig Hjarvard \& Mia Lövheim (eds.), Mediatization of Religion: Nordic Perspectives (Göteborg: Nordicom, Göteborgs Universitet, 2012), 95-108.

24 On 'trigger themes,' see Aina Landsverk Hagen, Meningers mot: Netthat og ytringsfrihet $i$ Norge [The Courage of Opinion: Hating Online and Freedom of Expression in Norway] (Oslo: Cappelen Damm Akademisk, 2015), 116-118. See also Enli, “Gate-keeping," 54-57; Michailidou \& Trenz, "Mediatized"; Figenschou, Thorbjørnsrud, \& Grøndahl Larsen, "Mediatized."

25 I employ the concepts 'performing conflict,' 'dramaturgy,' 'enactment of conflict,' and 'performative agency' based on my reading of Hjarvard, Mortensen, \& Eskjær, "Three”; Sumiala, "Ritual"; and Chouliaraki, "Mediatized." I borrow the term "emotional cues" from Figenschou, Thorbjørnsrud, \& Grøndahl Larsen, "Mediatized," 131. My understanding and 
particularly interested in the group dynamics that may come into play amongst social media actors during a mediatized conflict. How social media users engage with one another-put forward and evaluate each other's statements-is in my view part and parcel of users' performative agency and power to shape the conflict itself.

In the Yes to Wearing the Cross Whenever and Wherever I Choose online milieu, stances rarely stand entirely uncontested. Hence, this Facebook page can be viewed as a mediatized religious environment where identity politics and religious disputes are openly played out. As shall be demonstrated, the performance of the conflict entails both constructions and contestations of religious realities and religiously grounded positions, and formations, negotiations, and reconfigurations of religious and non-religious identities (both individual and national).

The Facebook page is thus a suitably rich empirical site and context from which to examine the multiple ways in which social media users co-construct, enact, and perform religio-political conflict. More specifically I examine: (1) What characterizes the repetitive patterns of communication observable in the group? (2) Which positions and roles do debaters take when enacting the conflict? (3) In what ways do users' performative agency transform, intensify, subdue, or generate new conflicts or otherwise influence the dramaturgy of the conflict?

In terms of method, I observed (and logged) interactions, repetitive communication patterns, positions, and roles in the group during the first weeks of peak activity from 4 November 2013 through 13 December $2013 .{ }^{26}$ I conceptualize my research as a (time-delayed) online ethnographic fieldwork of the Yes to Wearing the Cross Whenever and Wherever I Choose Facebook group. In a sense, my observations can be considered a form of non-participant observation because I observed discussions that have already taken place, and I am not a member of the group I am studying. ${ }^{27}$ I used NetCapture (a Google

use of the term 'emotional cues' also draws on the concept "emotionally charged phrases," as employed by Michailidou \& Trenz, "Mediatized," passim.

26 This period covers the weeks with the highest levels of activity and discussions and, during this timeframe, all postings are related to the NRK cross case. Discussions on the Yes to Wearing the Cross Whenever and Wherever I Choose Facebook page are still going strong, including a wide range of issues that pertain to the cross and Christianity in Norway and, at times, the world at large. The Facebook group is still active as of the time of writing this in June 2016.

27 During the process of data collection, I quickly discovered the benefit of not being logged into Facebook while collecting the data, as my name and profile picture would then not feature numerous times in the material for coding. 
Chrome extension) to archive the Facebook discussions for coding purposes in the qualitative analysis software program Nvivo. ${ }^{28}$ The Facebook group is open, and I did not need to log on to my Facebook account to observe the interactions that went on in the group. As such, it is evident that I did not influence the online milieu but instead observed what had already happened. ${ }^{29}$ Most importantly, such an approach allows for a deeper study of group dynamics and performance of conflict in a particular environment at the very peak of the conflict.

The introductory quotes are reconstructions of arguments from the Yes to Wearing the Cross Whenever and Wherever I Choose Facebook page. They represent common positions among debaters and illustrate repetitive patterns of communication and modes of enacting the conflict. I treat the Facebook group discussions as interactional transcripts and consequently conceptualize them as my field notes. It is these field notes that I coded. In addition, I kept a field diary, which includes a log of technical and methodological queries and challenges, adjustments of the substantive codes, and preliminary analysis and reflections. I coded the data within four main codes: themes, roles, styles, and arguments. ${ }^{30}$ The codes function as a springboard to further analysis. I write in ethnographic present.

28 Each individual post, with the debate and comments it sparked, is saved as a PDF. NetCapture creates a PDF of Facebook posts with all the comments, but entails a meticulous eye for detail on the part of the researcher in terms of including all the comments and replies to replies on a post that may have elicited a very high level of activity. Furthermore, it is worth noting that one of NetCapture's ways of 'capturing' the data entails giving the application highly intrusive access to nearly all the information on one's Facebook profile and the profiles of friends. I chose the option that did not grant such access, but it may possibly be more tedious in terms of usage.

29 This applies to the timeframe of study. It is important to note that the research is not covert and the moderator of Yes to Wearing the Cross Whenever and Wherever I Choose announced my research in the group and provided a link to my university profile page. Discussions that took place immediately after this announcement may possibly be influenced by the knowledge that a researcher was analyzing interactions, but these interactions are not included in my timeframe. The announcement of my study did elicit some response amongst the group members, mostly in the form of confirmation of the importance of studying this group, along the lines of this possibly affecting the cause in positive way.

30 I code using Emerson et al.'s approach to ethnographic coding and 'memoing.' This approach builds on grounded theory and seeks to systematically analyze 'by coding in close': "Grounded theorists give priority to developing rather than verifying analytic propositions. [...] at the actual working level, the researcher begins by coding data in close, systematic way so that he can generate analytic categories. He further elaborates, extends, 
Securing informed consent from all the individuals who have participated in the Facebook group is considered infeasible due to the sheer volume. ${ }^{31}$ Still, the research design takes into account that some users may conceive of the space as private even if it is an open Facebook group with over 100,000 more or less active users. ${ }^{32}$ Verbatim quotations from the Facebook discussions therefore necessitate informed consent from participants. The administrator of the Facebook group has consented to the study of the Facebook group. ${ }^{33}$ All quotations from the group in this article are my reconstructions of common utterances and sentiments and repetitive communication patterns and not verbatim quotes.

In the next section, I will introduce the Facebook group, its dynamics, and participants.

\section{2 \\ Campaigning for the Cross on Facebook: All Aboard?}

\subsection{Introducing the Case}

The NRK anchor's cross sparked the debate and led to the establishment of the Facebook group Yes to Wearing the Cross Whenever and Wherever I Choose in November 2013, which receieved over 120,00o likes. ${ }^{34}$ However, it is important to note that, even from the very start, the cross case functions as a springboard to numerous other religio-political debates within the Facebook group. In this sense, the scope of the group's discussions by far supersedes the original protest campaign.

and integrates these categories by writing theoretical memos." Robert M. Emerson, Rachel I. Fretz, \& Linda L. Shaw, Writing Ethnographic Fieldnotes (Chicago: University of Chicago Press, 1995), 143.

31 The research design follows recommended guidelines in Norwegian National Research Ethics Committees, "Ethical Guidelines for Internet Research," National Committee for Research Ethics in the Social Sciences and the Humanities, December 2014. https://www .etikkom.no/en/ethical-guidelines-for-research/ethical-guidelines-for-internet-research/ (accessed 4 December 2015).

32 Many researchers (myself included) argue that it is necessary from a research ethics point of view to take into consideration internet users' perceptions of private online space. For an elaboration on this theme, see Anette N. Markham \& Nancy K. Bayam, Internet Inquiry: Conversations about Method (California: SAGE Publications, 2009).

33 Information about the ongoing research, the research project, and how to contact the researcher has been posted on the Facebook page to ensure transparency.

34 The number of 'members' or 'likes' fluctuates, as some leave the group and new members join. 
Typically, posts on Yes to Wearing the Cross Whenever and Wherever I Choose are news-stories posted by the administrator coupled with his personal introduction. The comments from participants in the Facebook group deal with the news story and/or introduction to a varying degree. In the administrator's own rendition, he says he does not have the capacity to moderate the group, but that he has blocked or deleted 10-15 users from the Facebook page due to extremist views. ${ }^{35}$ He says his aim is to allow for a vibrant debate but draws the line at vulgar language and hateful comments.

On a general level, the discussion will thus provide layered insights on how mediatized conflicts about religion and media are instigated and performed in particular social contexts by social media users. The goal is to shed light on the role of participatory audiences in framing and amplifying mediatized conflicts about religion, especially on the ways in which conflicts are intensified or subdued. As the introductory (reconstructed) arguments from the Facebook page illustrate, a variety of stances do co-exist in this online milieu, even if there appears to be a slant in favor of particular positions, arguments, and modes of conflict performance - a point I will return to. In the following, I will outline what characterizes the debate on the Facebook page.

\subsection{Characteristics of the Facebook Group Debate Climate}

Yes to Wearing the Cross Whenever and Wherever I Choose carries the characteristics of many other types of online environments. By virtue of its thematic focus (initially, a focus on protest), it appeals to particular interest groups, such as conservative Christians and nationalists. ${ }^{36}$ In this sense, the Facebook

35 Personal communication. Cited with the administrator's informed consent.

${ }_{3} 6$ While Kushin and Kitchener appear to be arguing that Facebook facilitates a more productive and civil type of conversation, I do not subscribe to this view. In my opinion, social network sites, such as Facebook, do not in themselves encourage civil conduct or productive arguments any more than they encourage confrontational or battling styles of interaction. It is important to examine what types of audiences get pulled into the various online discussions or discussion groups. E.g., Enli, "Gate-keeping," 53-59, demonstrates that a high percentage of the participatory audience who interacted with a popularized political TV debate program had xenophobic and right-wing leanings. This appears to be true for a number of the participants in the Facebook group under study here too. However, this is in stark contrast to the Facebook group studied by Kushin and Kitchener, which is a group for those who are opposed to torture as an interrogation tool and, by implication, will attract a certain segment of society, with a likely overrepresentation of leftists. A group like Yes to Wearing the Cross Whenever and Wherever I Choose may arguably draw from Christian conservatives and others who rally for the visibility of Christianity in Norwegian society. Against this backdrop, it seems of utmost importance 
group can be defined as a 'special interest' group. Yet, Yes to Wearing the Cross Whenever and Wherever I Choose also attracts debaters who do not share the group's main point of departure, which makes for a very lively and at times livid debate climate, the intricacies of which I will delve into, shortly. Hence, the site gives us a unique insight into the performative agency of a range of actors involved in performing the conflict online.

\subsubsection{The Spectacular Echoes of the Cross Ban}

As an observer, one may feel overwhelmed by what appears to be the dominant mode of conflict performance. The sheer number of posts that argue that Muslims and immigrants are to blame for the cross ban, that there is no freedom of speech or freedom of religion in Norway, or claim that there is a general cross ban in Norway is somewhat daunting. Certainly, the conflict is frequently enacted through amplification, transformation, and the generation of new conflicts. Indeed, one of the most extraordinary characteristics and amplifications of the conflict on this Facebook page is what can be described as an expansive understanding of for whom the cross is perceived as forbidden for. While the cross is initially understood as being prohibited for NRK news anchors, the understanding gradually expands to include all employees of NRK, after which all employees in the public sector are considered to be bound by a cross ban, and then finally, the prohibition is envisioned as applying to all Norwegians. In the imaginations of the most active participants in the online discussions on Yes to Wearing the Cross Whenever and Wherever I Choose, the conceptualizations of the 'cross ban' are ever expansive. Hence, the prohibition of the cross is increasingly understood as a national ban in this online milieu. This is an example of the aforementioned spiraling argumentation style, sparked by a trigger theme, which in turn induces emotive responses. In this article, I will demonstrate how this very spectacular understanding of the cross ban is both a core characteristic of the debate while simultaneously also a highly contentious trait of performing the conflict for the debaters themselves.

\subsubsection{The Bigger Picture: Echo Chambers vs. Trench Wars}

Even if the escalating understanding of the cross prohibition is a fascinating phenomenon, it is important to note that these are not the only voices or arguments in this online environment. In line with Rune Karlsen's and his

to not only discuss the type of theme, but also discuss the ideological sympathies represented amongst the debate participants before making claims about Facebook inherently inducing a more civilized or uncivilized debate. 
colleagues' argument, this Facebook group does not function unequivocally like an echo chamber. ${ }^{37}$ That is, even if certain positions and arguments appear to dominate many discussions, few views stand unchallenged. Indeed, a spectrum of stances and arguments are put forward in the Yes to Wearing the Cross Whenever and Wherever I Choose group that reflect the various modes of performing the conflict. In this sense, the Facebook group can be considered an exemplification of Karlsen et al.'s argument that even in a special interest online context where many likeminded individuals discuss and resound their ideas with one another, there will also be participants who voice opposing views. Hence, Karlsen et al. argue that 'trench war' may be a more suitable metaphor than 'echo chambers' to capture the fact that few online debates take place in exclusively supportive environments. Rather, ideas are often challenged and battled out online. Yes to Wearing the Cross Whenever and Wherever I Choose is no exception. Hence the 'spiral of silence' may perhaps not be the best metaphor for this context.

In fact, a variety of enactments of the conflict and a spectrum of stances have been competing for attention in this Facebook group, from the very first instant it was created. The discussions are manifold and the many participants who join in the online discussions and who perform the conflict represent a range of positions and take on variety of roles. One fascinating feature of the debates in the group is the omnipresence of emotion. This is an important reminder that affect is part of politics. ${ }^{38}$ I will give a general overview of the group before delving into a more specific slice of the empirical data.

\subsubsection{Christianity and 'the Rest'}

Predictably, one of the themes that receives a lot of attention in the Facebook group Yes to Wearing the Cross Whenever and Wherever I Choose is 'Christianity.' What is interesting is that so many different stances on 'Christianity and the rest' are expressed. Some debaters see Christianity as inherently positive. A related position is to consider Christianity better than other religions. This is often intertwined with the idea that Christianity is 'Norwegian.' Together these arguments build up to the view that Christianity ought to receive special privileges in Norway. Another stance is that Islam is a terrible religion. This postulate is often paired with the idea that Islam is foreign. Taken together, the verdict is that Islam ought to be shunned. Yet another viewpoint

37 Karlsen et al., "Echo."

38 Liesbet van Zoonen, Entertaining the Citizen: When Politics and Popular Culture Converge (Lanham: Rowman \& Littlefield, 2005), 16-18. 
emphasizes the merits of secularism and treating all religions equallywhether that treatment is favorable or not. An alternative standpoint is that all religions are equally ridiculous. A detailed discussion of these stances is beyond the scope of this article. Suffice it to say, a multitude of views are expressed within the group Yes to Wearing the Cross Whenever and Wherever I Choose. Moreover, the example of 'Christianity' and 'the rest' illustrates how opinions rarely stand uncontested or without a countering argument in this online environment.

This is not to be confused with which arguments appear to carry the most clout. In part three, I will discuss in more detail, how different viewpoints play into the dynamics of the conflict and tug at the strings of identity politics. Next, I outline the recurrent types of participants in the Facebook group.

\subsection{Warriors and Pacifists: Types of Participants}

Broadly speaking those who are the most active on Yes to Wearing the Cross Whenever and Wherever I Choose and the enactment of the conflict(s) can be divided into five clusters of participants, which I will outline below. These are 'types,' which are my own constructions based on the analysis of repetitive patterns of communication. In the following, I will sketch out their characteristics, with regards to their positions, roles, and modes of performing the conflict.

Conservative Christians often express that they feel marginalized in Norwegian society due their conservative religious views. Their main point of departure is that atheists, secularists (Norwegian: 'humanetikere'), and/or Muslims wish to eradicate Christianity from Norway. Conservative Christians zealously focus on preserving Christianity in their performance of the conflict.

Nationalists often express xenophobic views with or without explicit Christian leanings. These individuals extensively focus on the preservation of 'Norwegian heritage.' In the nationalist co-structuring of the conflict, their main point of departure is that Norway is threatened by Muslims, immigrants, socialists, secularists, atheists, or a conspiratorial combination of the above.

Humanists tend to explicitly identify with either a humanistic Christian or secular worldview and take on the role of mediators. Their performative agency is navigated by the objective of calmly steering the debate into a more reconciliatory direction. The humanists are 'pacifists' in the sense that they attempt to implement a cease-fire and reduce the lines of conflict.

Fortified secularists repeatedly list all the benefits of Norway being a secular nation, and the crux of their performance of the conflict is to ferociously battle with xenophobic and Islamophobic ideas. 
Ardent atheists explicitly identify as atheists and vehemently oppose Norway being classified as a Christian nation. Their main involvement in this milieu and the conflict(s) is to belligerently push an aggressive atheist agenda. ${ }^{39}$

\subsubsection{Roles}

Individual debaters take on a variety of roles in the debates and hence enact the conflict in a multitude of ways that effect the dramaturgy of the conflict and its outcomes. Debate roles are fluid and transitional in the sense that the same individual will often take on various roles and argumentation styles thereby exhibiting performative agency in a variety of ways. Interestingly, some roles overlap with a category of participants. For example, humanists are more likely to play the role of 'preachers of tolerance' or 'pacifists.' Conservative Christians and ardent atheists or fortified secularists often enact the conflict by taking on a 'warrior role,' debating their perspectives fervently. Indeed, the performance of conflict can seriously heat up with the sweltering comments of warriors. Nonetheless, it is invariably the ardent atheists who pair the warrior role with 'flaming behavior.' ${ }^{\prime 0}$ In this context, flaming behavior can be viewed as a form of performative agency that exploits the full potential of emotive cues. By flaming behavior, I mean entering a debate, bellowing antagonistic commentary or insults, and then retreating. ${ }^{41}$ Flaming behavior can be characterized as more one-sided than other observable interactions between others in warrior roles, cueing in and leaving the rest of the participants to continue the discussion long after the flamer is gone. For, while other warriors tend to vehemently argue their own stance, they nonetheless appear to be interested in a two-way discussion or conversation, even if only in theory. This is evident

39 In this article, all references to types of participants, such as 'conservative Christians,' 'nationalists,' etc., refer exclusively to the debaters in the case-study unless otherwise specified.

40 I would like to thank Charles Ess for valuable input on the distinction between being a 'flamer' and having 'flaming behavior.'

41 Here I draw on the definition of 'flaming' presented in Landsverk Hagen, Meningers, 116. My own understanding of the term 'flaming' deepened during the ethnographical study of this group. At first, I was employing the term liberally, but the longer I observed variations of conduct in this online environment, the more I realized that the term 'flaming' is not very useful as analytical category unless it signifies something more specific or elaborate than simply passionately stirring up a debate. Gradually, I observed that the conduct of ardent atheists is distinct from the behavior of all other types of participants and warrants being described as 'flaming behavior.' 
by the fact that the warriors who do not exhibit flaming behavior often show more stamina with regard to actively participating in many debates and repeatedly battling out their ideas online. ${ }^{42}$ For these participants, stamina and performing the conflict for a significant amount of time can be seen as key to their enactment of the conflict.

\subsubsection{Motivations}

At first glance, it may appear as if all those active in this particular debate environment participate because they have a clear religious, ideological, or political agenda. It can certainly be argued that many of the comments posted in Yes to Wearing the Cross Whenever and Wherever I Choose speak to particular stances on religion and identity politics. There is, however, a danger of overemphasizing the ideological intent of the individual debaters. Hence, it is important to take into consideration that many participants may be performing the conflict for other, more mundane reasons, such as letting off steam, boredom, or the need for entertainment, a point I shall return to. ${ }^{43}$ Still, one can observe some differences in the modes of performance amongst participants of the various categories, which may hint to ideological motivations. For instance, the ardent atheists often participate briefly in a debate, by dispensing an antagonistic atheist agenda a few times before disappearing into thin air. This suggests that the ardent atheists may be more intent on performing the conflict in a manner that leaves a mark on the debate than actually engaging in an exchange of positions. Similarly, the humanists' intentions of performative agency appear to be rather self-evident, that is, to facilitate a more rational debate, and ultimately, achieve reconciliation and a cease-fire amongst warriors. The intent to promote a tolerant and/or rational debate and reduce conflict is often explicitly expressed by humanists and lies at the very heart of their enactment of the conflict.

\subsubsection{Volume}

Conservative Christians and nationalists are characterized by being the most voluminous in terms of the number of Facebook profiles/individuals and

42 Kushin \& Kitchener, "Getting," describe similar types of variations in their study of political debates on Facebook. They refer to 'civil' and 'uncivil' forms of behavior and 'productive' and 'unproductive' argumentation styles.

43 Eli Skogerbø \& Marte Winswold, "Nettet som debattarena [The Internet as a Platform for Debate]," in: Gunn Enli \& Eli Skogerbø (eds.), Digitale dilemmaer: Nye medieformer, nye utfordringer [Digital Dilemmas: New Types of Media, New Challenges] (Oslo: Gyldendal Akademisk, 2008), 39-59, at 48. 
comments. ${ }^{44}$ Their enactment of the conflict can be said to dominate the page, and, hence, conservative Christians and nationalists play an active role in shaping the conflict(s) and the outcomes, as will be substantiated further. The other types of participants consist of far fewer individuals/profiles. Particularly in the case of the humanists, a handful of individuals are extremely active in performing the conflict and, in effect, are behind most of the posts from this group. Humanists greatly influence the dramaturgy of the conflict by consistently co-structuring the conflict and re-mediating the conflicts in a reconciliatory manner. A couple of the humanists' performative agency really stands out, as they have left their mark on an incredibly large number of debates. This is a very noticeable trait unique to the humanists. Fortified secularists and ardent atheists, much like the humanists, are overwhelmingly outnumbered by the nationalists and conservative Christians. However, individual ardent atheists enact the conflict in a way peculiar to them-they appear to flame a couple of debates and then detach themselves from further discussions. Hence, unlike the other groups of participants, one can only detect the performative agency of ardent atheists in a limited amount of discussions in the Facebook group. Ardent atheists' unique mode of performing the conflict entails sporadically targeting and flaming particular debates in the Yes to Wearing the Cross Whenever and Wherever I Choose Facebook group and then disappearing. The next section will elucidate how the different types of participatory audiences contribute to amplifying the conflict in various ways.

\section{Friends and Foes of the Cross Ban Claim: A Playground for Identity Politics}

The escalating understandings of the cross prohibition and the general cross ban claim in Yes to Wearing the Cross Whenever and Wherever I Choose stir up all types of participants, albeit for different reasons. Hence, this example is well suited to tease out some of the dynamics of the mediatized conflict that are at play among the participants. It points to the various modes of enacting the conflict and sheds light on how the participants' evaluation of and interaction with one another's positions is an integral part of their performative agency.

44 There is, of course, a hypothetical possibility that some users have created more than one Facebook profile and are commenting under several names. I have not scrutinized this further. 


\section{Warriors in Defense of the Cross}

The cross is forbidden in Norway!

Preserve Christianity!

There is no religious freedom in Norway!

Conservative Christians often enact the conflict by taking on the warrior role and arguing that Christian rituals and traditions run the risk of being eradicated from the public sphere in Norway, the prime example of which is the (alleged) cross ban in Norway. This is an example of how conservative Christians tailor their performance of the conflict to an emotive cue, which amplifies the conflict. Part and parcel of their performative agency is the blaming game.45 The usual suspects behind the ban include atheists, secularists, and Muslims. It ought to be noted that there are a few stray conservative Christians who express confusion over the alleged cross ban. Nevertheless, the perceived ban is the main frame of departure amongst the conservative Christians and serves to amplify the conflict(s). More specifically, conservative Christians' enactment of the conflict sparks appeals to increase the visibility of the cross in multiple ways, examples of which include calls to wear cross-pendants, to buy (and wear) a cross, or to acquire a cross tattoo. Indeed, many conservative Christians formulate their support for the cross as an act of defiance to the alleged cross ban, exclaiming things like, 'I will wear the cross even if it is forbidden!', and 'You cannot stop me from wearing the cross!"46 Some conservative Christians or nationalists take the act of defiance one step further, rhetorically asking how anyone can prohibit them from their right to draw a cross with permanent ink on their body, often followed up by a somewhat melodramatic question such as: 'What will they do to stop me—cut off my arm?!'47 This represents a type of performative agency — which adds to the dramaturgy of the conflict — and can be viewed as an example of a biased, spiraling, and emotive response, which serves to both intensify the conflict and reproduce a conservative Christian identity. ${ }^{48}$

45 Mona Abdel-Fadil, "Conflict and Affect among Conservative Christians on Facebook," Heidelberg Journal of Religions on the Internet 11 (2016), 1-27, at 19 .

46 What I present in this article is the general trend amongst conservative Christians. There are exceptions, such as conservative Christians who express confusion over the tensions in the debate since they themselves have never experienced any negative reactions to wearing a cross-pendant in their everyday lives.

47 It is not all together clear who 'they' refers to in arguments of this type.

48 At times, conservative Christians operate with a clear Christianity vs. Islam dichotomy, which resonates well with the nationalists. This gives rise to arguments, such as, "They 
The envisioned cross ban gives rise to the claim that 'there is no freedom of religion in Norway' and contributes to transforming the conflict. ${ }^{49}$ Conservative Christians perform the conflict in a manner which amplifies the conflict by claiming that one cannot fully and freely be Christian in one's own country, which ties in with their fears of not being able to uphold Christian rituals and traditions in Norway. Against this backdrop, the (imagined) ban on the cross is perceived and performed as an attack on Christian identity, which in turn requires a rigorous defense. ${ }^{50}$ This defense takes place through enacting the conflict via trigger themes, which draw out selective attention and emotive and spiraling modes of argumentation.

Conservative Christians on the Facebook page tend to argue that there is a general cross ban in Norway, thereby distorting, amplifying, and co-constructing the conflict in a fashion that prolongs the conflict. Since conservative Christians are amongst the most visible participants in the Facebook group, their performative agency of amplifying the conflict is substantial.

Next, I will demonstrate how nationalists' enactment of the conflict contributes to the transformation of the conflict(s).

\subsection{Warriors in Defense of the Nation}

Muslims are to blame!

Immigrants threaten Norwegian culture!

practice Islam and we cannot practice our own religion in our country.' In a similar vein, not being able to wear the cross is often contrasted to Muslims who are able to wear hijabs in public. These perceived realities are considered incredibly unjust and give rise to a cross-hijab dialectical argument of the type: 'If they can wear hijab, we should be able to wear the cross.'

49 The reference to 'religion' in this context is—in my reading — a reference to 'Christianity.'

$5^{0}$ Here, I draw on Amin Maalouf's discussion of threatened identities. See Amin Maalouf, In the Name of Identity: Violence and the Need to Belong (London: Penguin Books, 1996). Maalouf discusses the danger of essentializing identities and equating one's identity to one singular identity tag, such as religious affiliation, because it increases the likelihood of feeling threatened. Being under attack requires a defense, and those who feel besieged by enemies may be willing to go to great lengths to defend themselves. These are philosophical reflections, originally developed in response to: (1) the act of reducing people with (presumed) Muslim affiliation to only one identity tag, namely 'Muslim'; and (2) the dialectical process in which some individuals of Muslim background may themselves increasingly identify with an essentialized 'Muslim' identity and gradually feel threatened by cumulative antagonistic media portrayals of Muslims. 
Nationalists tend to argue that Norway is going to the dogs due to Muslims, immigrants, socialists, secularists, or atheists or a conspiratorial mix of all of the above. Nationalists use their performative agency to scapegoat others, are heavy on emotional cues, and excel at igniting emotive responses through trigger themes. Much like the conservative Christians, nationalists commonly take on the role of warriors and contribute to an intensification of the conflict by distorting the facts of the cross ban. More specifically, nationalists enact the conflict in ways that transform the conflict into one between Norwegians and immigrants and between Christians and Muslims. In effect, the nationalists transform the conflict into a field of xenophobic and Islamophobic sentiments, a transformation which appears to be condoned by some conservative Christians.

There appear to be overlaps and continuities in the sentiments and modes of enactment of the conflict among Christian conservatives and nationalists, which makes the distinction between the two types of participants slightly fuzzy. ${ }^{51}$ Still, typically, nationalists care less about Christianity per se and more about 'Norwegianess.' Nonetheless, there is a tendency amongst both conservative Christians and nationalists to conflate 'Norway' with 'Christianity' in their co-structuring of the conflict. 'Christians' are 'Norwegians' and vice versa in the sense that the identity tags 'Norwegian' and 'Christian' are considered one and the same. In a similar vein, even amongst nationalists who openly state their lack of affiliation to Christianity, the cross is viewed as 'Norwegian' and worthy of defense in a manner that drives the conflict forward. Both nationalists and conservative Christians perform the conflict in such a way as to evoke worst-case scenarios that spiral out of a 'what next?' or 'slippery slope' type of argumentation. The most common example of this in the debates on Yes to Wearing the Cross Whenever and Wherever I Choose are references to how erasing the cross from the Norwegian flag will be next in line, which serves to amplify the conflict. This 'what next?' example is well suited to swell concerns of further losses of identity symbols, since it ignites the emotions and existential anxieties of both conservative Christians and nationalists alike. This type of co-structuring of the conflict alters the dramaturgy of the conflict and generates new conflicts that rely heavily on emotive cues and responses.

Nevertheless, the nationalists' modes of enacting the conflict may be considered the most expansive in their distortions and in their modes of

$5^{1} \quad$ Nationalists have a stronger emphasis on politicians (but also, here, there is an overlap with the conservative Christians). They give examples of living in a socialist/leftist dictatorship and do not shy away from describing Norway as the equivalent of 'North Korea.' Similar findings were identified in climate debates in Michailidou \& Trenz, "Mediatized." 
scapegoating and othering. Moreover, in their re-mediations of the conflict(s), nationalists seem to equate 'Norwegian heritage' with being white and nonMuslim, and their enactment of the conflict betrays a language more aggressive and more explicitly derogatory than other actors. For instance, Muslims and immigrants are commonly viewed as 'contaminating' Norway. Some of the nationalists co-structure and perform the conflict in a fashion reminiscent of far-right ideologies, exemplified by classifying 'all Muslims and/or immigrants' as 'thieves,' 'rapists,' 'murderers,' or the more generic 'criminals' or, indeed, as all of the above. Nationalists as a whole express that Muslims and/or immigrants threaten Norwegian culture. This is often accompanied by a sense of urgency and formulated as a 'wake-up call', implying that if (white) Norwegians do not wake up now, they will suffer the permanent takeover of Norway by Muslims and/or immigrants. These acts of devaluation can be interpreted as part and parcel of the nationalists' performative agency by which they generate new conflict(s) and evoke emotive reactions from other debaters. Nationalists also tend to express belief in conspiracies reminiscent of Eurabia theories, in which Muslims and European politicians are seen as conspiring to turn Europe into an Islamic caliphate ruled by Sharia. ${ }^{52}$ Sindre Bangstad, drawing on Arjun Appadurai, argues that the Eurabia genre is inspired by "fear of small numbers," i.e., what I have previously termed "existential anxiety" and classified as a fear of marginalization. ${ }^{53}$ The framing of the conflict in this manner draws on emotional cues and, for the most part, triggers emotional responses that in return further amplify the conflict(s).

By delving into the very core of identity politics, the 'what next' arguments, worst-case scenarios, and Eurabia conspiracies trigger emotive cues and existential insecurities or what Appadurai calls "fear of numbers," thereby erupting a volcano of seemingly overwhelming emotions amongst both nationalists and conservative Christians. ${ }^{54}$ This sets the stage for channeling existential

$5^{2}$ More specifically, those who buy into the Eurabia genre consider Muslim migration to Europe, coupled with high fertilization rates amongst Muslim women, as evidence of the intent to take over Europe. The translation of 'Sharia' as 'Islamic law' is, in fact, a very inaccurate translation since there is no consensus on what exactly constitutes Islamic law, nor are laws derived from the so-called Sharia (that deal with the same legal matter) identical. See Mona Abdel-Fadil "Hvilken Sharia? [Which Sharia?]: Problemer knyttet til begrepet," Babylon: Nordisk tidsskrift for midtøstenstudier 2 (2003), 20-25.

53 Sindre Bangstad, Anders Breivik and the Rise of Islamophobia (London: Zed Books, 2014), 144; Mona Abdel-Fadil, "The NRK Cross-Case as a Catalyser for Existential Anxieties, Digital Existence," Memory, Meaning, Vulnerability, conference (Sigtuna, 2015).

54 Quoted in Göran Larsson, "The Fear of Small Numbers: Eurabia Literature and Censuses on Religious Belonging," Journal of Muslims in Europe 1/2 (2012), 142-165, at 147. 
anxieties into spiraling arguments that transform the conflict into a platform for the highly contentious propagation of xenophobic and Islamophobic opinions.

\section{Warriors in Defense of Atheism, Secularism, and Anti-racism}

To hell with religion!

You are all imbeciles spewing out racism and ignorance!

Ardent atheists and fortified secularists most often enact the conflict in the role of warriors. These two types of participants appear to have a common loathing for the claim that Norway is a Christian country, which is sometimes argued by other debaters. Both ardent atheists and fortified secularists fervently oppose such claims and often do so by pointing to statistics of religious belonging and referring to the legal separation of church and state. At first glance, they appear to have similar and overlapping conduct and sentiments, but there are certainly differences that warrant elaboration. For instance, claiming that Norwegians are Christians appears to be a trigger theme solely for ardent atheists and leads to the unleashing of a range of negative emotions in their further enactment of the conflict. Also, the tone of ardent atheists is generally more aggressive at the outset in comparison to other types of participants. Debaters from this camp, upon entering into the lion's hole (of believers), state that all religions are nonsensical, irrational fantasies and all believers are imbeciles curbing Norway's advancement as a nation. This form of performative agency stirs up other participants not least because most ardent atheists spend their time dispatching general insults to all religions and all believers while simultaneously professing their own unsurpassed rationality and insight, while a notable few move on to personal insults. Ardent atheists perform the conflict in a way that amplifies and generates new conflicts. Indeed, most of the ardent atheists exhibit flaming behavior, in the sense that they appear to have entered this online space specifically to ignite a fiery debate and leave mid-fire. Thus, ardent atheists play an important role in spurring and transforming the debates in the Facebook group. And their enactment of the conflict leaves a mark even after they are long gone.

A striking feature of the way ardent atheist warriors perform the conflict and relate to the cross ban claims in Yes to Wearing the Cross Whenever and Wherever I Choose and the related calls to increase the cross's visibility in Norway is to attack the symbol itself. That is, ardent atheists argue that the cross is a symbol of ignorance, arrogance, and violence, claiming that anyone wishing to associate with the symbol is, in short, an imbecile. Intriguingly, ardent atheists 
seem less concerned with the fictitious belief of a general cross ban in Norway held by conservative Christians than with arguing that Christianity itself is a work of fiction. Not only is the nation as Christian an emotional provocation for ardent atheists, but, in actuality, the mere mention of the word 'religion' sends their emotions soaring and hence seems to be their very motivation for enacting the conflict in this Facebook group in the first place.

In contrast, fortified secularists are arguably more angered by blatant racism and anti-Islamic sentiments than religiosity per se. Indeed, racist claims function as trigger themes for the fortified secularists. Moreover, they share the ardent atheists' distaste for irrationality. ${ }^{55}$ Nonetheless, for the fortified secularists, the epitome of irrationality is demonstrated by the ways in which conservative Christians and nationalists perform the conflict by repeatedly claiming that there is a cross ban in Norway and employing this as a platform from which to circulate xenophobic and Islamophobic opinions. In their costructuring of the conflict, fortified secularists express frustration with the conservative Christians and nationalists for acting like a flock of sheep, with a total disregard for checking the facts or listening to reason. The rhetorical approach of fortified secularists betrays both that they are responding emotively and that they have lost all patience with their co-debaters, in the sense that their modes of expression vary from general insults, such as 'You are all imbeciles spewing out racism and ignorance,' to targeted personal insults in which a person is named and accused of being ignorant or racist or both. ${ }^{56}$ Not only do fortified secularists evaluate the performance of other debaters, but they also-much like the ardent atheists-amplify the conflict by antagonizing other debaters. Hence, amplifying, transforming, and generating new conflicts are all part and parcel of fortified secularists' enactment of conflict in the Yes to Wearing the Cross Whenever and Wherever I Choose group.

In summary, both the ardent atheists and the fortified secularists succeed in generating new conflicts by focusing on the irrationality of, respectively, religious belief and racism or Islamophobia. They also polarize the debate climate further by generously dispatching insults to the other debaters as part of their performance. ${ }^{57}$ Nonetheless, both of these groups contribute to the

55 'Irrationality' is employed here as an emic term, i.e., as defined by the participants in question.

$5^{6}$ Generalized insults are by far the most common. Targeted personal insults are very rare among the ardent secularists, but I include them here since insults can be considered on a continuum ranging from the general to the personal.

57 This is not to say that the conservative Christians and nationalists do not return the insults once that type of climate has ensued. But, this type of reciprocation of insult is beyond the scope of this article. 
contestation of dominant perspectives within the Facebook group and thus substantiate that the Facebook group is perhaps best described as a trench war, rather than as an echo chamber. ${ }^{58}$

\subsection{Humanists in Defense of Pluralism and Tolerance}

All religions are equal!

Love thy neighbour!

Humanists identify as either (humanistic) secular or Christian and argue that the unhinged debates and the related anger and fear in Yes to Wearing the Cross Whenever and Wherever I Choose ride on the erroneous belief that the cross is banned in Norway. Thus, the humanists add another set of dynamics to the online debates that is not present in the other types of participants' contributions. Humanists' attempts to reduce and resolve the conflicts in Yes to Wearing the Cross Whenever and Wherever I Choose are palpable and lie at the very core of their performance of the conflict. ${ }^{59}$

On a general level, humanists express frustration with the tendency amongst debaters to blame Muslims or immigrants and try to deflate this misconception. While xenophobic sentiments constitute a trigger theme for the humanists too, they re-direct their exasperation into a different type of performative agency than the fervent secularists. Humanists enact the conflict by explicitly questioning a Christianity that promotes a xenophobic and/or Islamophobic worldview. ${ }^{60}$ Their co-structuring of the conflict displays a pluralistic view of religion, and they argue that all religions ought to be treated equally. One striking feature about the humanists is that they appear to be a pretty constant

$58 \quad$ Karlsen et al., "Echo."

59 Enli, "Gate-keeping," 53-59 refers to how her own work and other studies have shown that moderators and traditional gatekeepers may feed in fabricated 'balanced' audience messages in order to counter skewed and biased audience participation. What is interesting in the case of the Facebook group Yes to Wearing the Cross Whenever and Wherever I Choose is how social media users (represented by humanists) take it upon themselves to show a wider spectrum of views and try to counter slanted perspectives.

6o It ought to be noted that some debaters leave the group in protest and explicitly state their reasons for doing so. Most of those who leave appear to leave in protest to what they consider a xenophobic and Islamophobic debate climate. However, a number of debaters bid farewell to the group by stating that they refuse to be a part of a group where their views are 'censored.' 
group comprised of a few individuals. ${ }^{61}$ Yet, the humanists' activity and performative agency defies their numbers. Less than a handful of individuals are behind an impressive amount of activity, and they continuously try to steer the debates back to the facts of the matter and simultaneously contribute to a debate less driven by the politics of affect.

Particularly with regard to the alleged cross ban, humanists make significant efforts to counter the narratives that are put forward by the conservative Christians and nationalists. ${ }^{62}$ With much diligence, patience, and dedication, the humanists persistently (and repeatedly) try to debunk the myth that the cross is forbidden in Norway. When temperatures rise and the debate is dominated by conservative Christians and nationalists who enact the conflict by spilling out emotive reactions to their being barred from wearing the cross, humanists inexhaustibly try to soothingly explain that they can wear the cross as much as their heart desires since the cross is only prohibited for news anchors at NRK while reading the news. However, despite the repeated contestation of the cross ban, there is little evidence that many of the conservative Christians and nationalists actually listen to the counter-arguments or change their minds. It would appear that a confirmation bias is at play. In this sense, the humanists' attempts to subdue and reduce the conflict may possibly be to no avail.

\subsection{Reflections}

In effect, Yes to Wearing the Cross Whenever and Wherever I Choose becomes a locus for formations, negotiations, and reconfigurations of religious and non-religious identities (both individual and national) when performing the conflict. Those who consider themselves conservative Christian conflate their own personal Christian identity with that of the nation. They speak of Norway as a Christian country and of Norwegians as Christians. For the nationalists, Norway is for (white) non-immigrant Norwegians-who may or may not be Christian, but are certainly not Muslim. In the co-structuring of the conflict, Norwegian or alternatively Norwegian Christian identities are professed at both micro and macro levels. The humanists attempt to negotiate multiple identities and the level of the individual. Humanists also stand out because some of them identify as believers or devout Christians at the personal level, yet they maintain that Norwegian national identity ought to be secular and

61 'Constant' in the sense that the same individuals appear to be behind most of the comments in this genre.

62 A related enterprise taken on by the humanists is the discussion of Christianity in Norway. Humanists inform the debaters that Norway is technically speaking no longer a Christian country since Christianity is not the state religion any more. 
pluralistic in order to capture the diversity in the Norwegian population. $\mathrm{Hu}$ manists are the ones who by far hold the most inclusive approach to identity politics. As for the ardent atheists and fortified secularists, their main concern is to equate their personal identity - as either fervently atheist or secularwith that of the nation. Indeed, these negotiations of identities lie at the very heart of the performance that the various participants employ when contributing to either the intensification or the subduing of the cross-conflict(s). Intriguingly, this study illustrates that nearly all of the participants in an online milieu may contribute to the increased polarization of views, albeit in a variety of ways and for different reasons.

\section{$4 \quad$ Concluding Remarks}

If media anthropologists are to dismiss all social media campaigns or 'politically charged moments' as uninteresting for ethnographic study, they run the risk of both missing out on acquiring important insights on how social media actors perform conflict in the heat of the moment and overlooking transitions from extraordinary campaigns to permanent structures. Indeed, as the Facebook group Yes to Wearing the Cross Whenever and Wherever I Choose illustrates, a 'politically charged moment' can last for months on end and even years. ${ }^{63}$

By virtue of the group's name, it is reasonable to assume that this space will draw in a certain type of people with specific personal religious sentiments and political leanings, all or most of whom are sympathetic to the cause. Yet, even within this special interest group, the analysis illustrates how the conflict attracts a variety of social actors, who dive into the heart of the conflict-with potent performative agency - in order to co-structure the conflict in ways that explicitly contradict the aims that originally sparked the establishment of the group.

A spectacular feature of Yes to Wearing the Cross Whenever and Wherever I Choose is the widespread propagation of there being a general cross ban in Norway. Yet, upon close examination, the performance of conflict in this online milieu reveals a spectrum of constructions and contestations of religious

63 In the case of Yes to Wearing the Cross Whenever and Wherever I Choose Facebook, this is applicable to the time of its formation in November 2013 to the present (as it is still an active environment as of the time of writing in June 2016), nearly two years after the 'ad hoc' issue was resolved. 
realities and religiously grounded positions, which better fit the 'trench war' metaphor. Even if the Facebook group cannot be accurately characterized as an 'echo chamber', there appears to be a confirmation bias in favor of the 'cross ban' position, thereby lending support to Karlsen et al.'s argument that the existence of counter-arguments does not necessarily lead to a re-evaluation of the original stance. As Karlsen et al. argue, one of the factors that appears to work in favor of confirmation bias is strong conviction of one's own stance, which arguably is relevant to all types of participants in the Yes to Wearing the Cross Whenever and Wherever I Choose group.

The cross-conflict and its enactment in Yes to Wearing the Cross Whenever and Wherever I Choose demonstrates how social media users who engage in mediatized conflicts with inherent trigger themes that tug at core religopolitical identity issues, also tend to evoke emotional responses, which in turn amplify or multiply the conflict(s). Hence, the various audience amplifications of the mediatized conflict are perhaps best characterized as 'politics of affect.'

Contrary to previous research where the findings point to how social actors attempt to avoid conflict, my study illustrates how some social actors seem to enter this online space precisely because they appear to thrive in the contentious climate and enjoy performing and amplifying the conflict, albeit from a variety of ideological angles. This study points not to 'the spiral of silence,' but rather to 'the spiral of speaking out' - speaking out against the positions one disagrees with. Rather than engaging in conflict-avoidance, many actors face conflict head on. The dynamics of the bottom-up conflict as played out in this online milieu show that evaluating, interacting with, and contesting other actors' stances are not only an integral but possibly also a valued part of the performance of conflict.

In Miller's study, the findings point to how both Brits and Trinidadians tend to only discuss politics in social media when humor, scandal, or spectacle are involved and, hence, engagement with politics in social media is only viable as entertainment. Still, my own research demonstrates that we need to widen the definition of 'politics as entertainment' when studying interactions among users of social media.

The findings from the study of Yes to Wearing the Cross Whenever and Wherever I Choose show that entertainment is not always just about bantering or relishing in scandal, it can also be about the various modes of performing a conflict, such as throwing out emotive cues and trigger themes, bashing other debaters, or distorting and flaming debates. In short, performing and, particularly, amplifying the conflict may be a cherished form of (political) entertainment in itself. 


\section{Acknowledgments}

I am grateful to a number of my colleagues at the Department of Media and Communication, University of Oslo, who helped sharpen my focus and analysis. A special thanks to Karoline Ihlebæk and Terje Colbjørnsen for a series of stimulating conversations about online debates that inspired me to develop my work further and for their constructive feedback on an earlier draft of this article. Thanks are also due to Tine Ustad Figenschou, Bente Kalsnes, and Charles Ess for engaging academic conversations that shaped my thinking. And last, but not least, I would also like to thank Knut Lundby for his input and unfaltering enthusiasm for my work.

\section{References}

Abdel-Fadil, Mona, "Hvilken Sharia? [Which Sharia?]: Problemer knyttet til begrepet," Babylon: Nordisk tidsskrift for midtøstenstudier 2 (2003), 20-25.

Abdel-Fadil, Mona, "The NRK Cross-Case as a Catalyser for Existential Anxieties, Digital Existence," Memory, Meaning, Vulnerability, conference (Sigtuna, 2015).

Abdel-Fadil, Mona, "Conflict and Affect among Conservative Christians on Facebook," Heidelberg Journal of Religions on the Internet 11 (2016), 1-27.

Anderson, Alison, "The Mediatization of Environmental Conflict in the 'Network Society," in: Mikkel Fugl Eskjær, Stig Hjarvard, \& Mette Mortensen (eds.), The Dynamics of Mediatized Conflicts (New York: Peter Lang, 2015), 1-27.

Averbeck-Lietz, Stefanie, Andreas Hepp, \& Rebecca Venema, "Communicative Figurations of Financial Blogging: Deliberative and Moralising Modes of Crisis Communication During the Euro Crisis," in: Mikkel Fugl Eskjær, Stig Hjarvard, \& Mette Mortensen (eds.), The Dynamics of Mediatized Conflicts (New York: Peter Lang, 2015), 71-89.

Bangstad, Sindre, Anders Breivik and the Rise of Islamophobia (London: Zed Books, 2014).

Boltanski, Luc, \& Laurent Thévenot, "The Sociology of Critical Capacity," European Journal of Social Theory 2/3 (1999), 359-377.

Campbell, Heidi, When Religion Meets New Media (New York: Routledge, 2010).

Chouliaraki, Lilie, "Mediatized Death in the Post-Arab Spring Conflicts," in: Mikkel Fugl Eskjær, Stig Hjarvard, \& Mette Mortensen (eds.), The Dynamics of Mediatized Conflicts (New York: Peter Lang, 2015), 185-203.

Colbjørnsen, Terje, "Debating Freedom of Expression in Norwegian Media: Critical Moments, Positions and Arguments" in: Arnfinn H. Midtbøen, Kari Steen-Johnsen, \& Kjersti Thorbjørnsrud (eds.), Boundary Struggles: Contestations of Free Speech in the Norwegian Public Sphere (Oslo: Cappelen Damm Akademisk, 2017), 165-194. 
https://www.duo.uio.no/bitstream/handle/10852/56820/Boundary\%2Bstruggles _published.pdf?sequence=2. (accessed 7 November 2017).

CoMRel: Engaging with Conflicts in Mediatized Religious Environments, survey, 2014-2017. http://www.hf.uio.no/imk/english/research/projects/comrel/ (accessed 11 May 2017).

Dawson, Lorne L., \& Douglas E. Cowan, Religion Online: Finding Faith on the Internet (New York: Routledge, 2004).

Emerson, Robert M., Rachel I. Fretz, \& Linda L. Shaw, Writing Ethnographic Fieldnotes (Chicago: University of Chicago Press, 1995).

Enli, GunnS., "Gate-keeping in the New Media Age,"Javnost:ThePublic 14/2 (2007), 47-61. Figenschou, Tine Ustad, Kjersti Thorbjørnsrud, \& Anna Grøndahl Larsen, "Mediatized Asylum Conflicts: Human-Interest Framing and Common-Sense Public Morality," in: Mikkel Fugl Eskjær, Stig Hjarvard, \& Mette Mortensen (eds.), The Dynamics of Mediatized Conflicts (New York: Peter Lang, 2015), 129-145.

Gillespie, Marie, "Introduction: What Is the Audience and Why Is It Important?," in: Marie Gillespie (ed.), Media Audiences (Berkshire \& New York: Open University Press, 2005), 10-11.

Hjarvard, Stig, "Politik er farlig på Facebook: Sociale medier er ikke danskernes politiske forsamlingshus [Politics Is Dangerous on Facebook: Social Media Are Not Equivalent to Community Centers for Danes]," 2015. http://www.kommunikations forum.dk/artikler/Sociale-medier-er-ikke-danskernes-politiske-forsamlingshus (accessed 11 May 2017).

Hjarvard, Stig, Mette Mortensen, \& Mikkel Fugl Eskjær, "Three Dynamics of Mediatized Conflicts," in: Mikkel Fugl Eskjær, Stig Hjarvard, \& Mette Mortensen (eds.), The Dynamics of Mediatized Conflicts (New York: Peter Lang, 2015), 1-27.

Jurkiewicz, Sarah, "Being a Blogger in Beirut: Production Practices and Modes of Publicness," PhD diss. (Oslo: University of Oslo, 2012).

Karlsen, Rune, et al., "Echo Chamber and Trench Warfare Dynamics in Online Debates," European Journal of Communication (2017). http://journals.sagepub.com/ doi/full/10.1177/0267323117695734 (accessed 9 May 2017).

Kulturstyrelsen, "Sociale medier brug, interesseområder og debatlyst [Social Media Use, Interests, and the Desire to Debate]," 2015. http://slks.dk/mediernes-udvikling -2015/specialrapporter/sociale-medier/ (accessed 11 May 2017).

Kushin, Matthew J., \& Kelin Kitchener, "Getting Political on Social Network Sites: Exploring Political Discourse on Facebook," First Monday 14/11 (2009). http://first monday.org/ojs/index.php/fm/article/view/2645/2350 (accessed 4 December 2015).

Landsverk Hagen, Aina, Meningers mot: Netthat og ytringsfrihet $i$ Norge [The Courage of Opinion: Hating Online and Freedom of Expression in Norway] (Oslo: Cappelen Damm Akademisk, 2015).

Larsson, Göran, "The Fear of Small Numbers: Eurabia Literature and Censuses on Religious Belonging," Journal of Muslims in Europe 1/2 (2012), 142-165. 
Livingstone, Sonia, "Media Audiences, Interpreters and Users," in: Marie Gillespie (ed.), Media Audiences (Berkshire \& New York: Open University Press, 2005), 9-50. Lundby, Knut, \& Kjersti Thorbjørnsrud, "Mediatization of Controversy: When the Security Police Went on Facebook," in: Stig Hjarvard \& Mia Lövheim (eds.), Mediatization of Religion: Nordic Perspectives (Göteborg: Nordicom, Göteborgs Universitet, 2012), 95-108.

Maalouf, Amin, In the Name of Identity: Violence and the Need to Belong (London: Penguin Books, 1996).

Markham, Anette N., \& Nancy K. Bayam, Internet Inquiry: Conversations about Method (California: SAGE Publications, 2009).

McClure, Paul K., "Faith and Facebook in a Pluralistic Age: The Effects of Social Networking Sites on the Religious Beliefs of Emerging Adults," Sociological Perspectives 59/4 (2016), 818-834.

Michailidou, Asmina, \& Hans-Jörg Trenz, "Mediatized Transnational Conflicts: Online Media and the Politicisation of the European Union in Times of Crisis," in: Mikkel Fugl Eskjær, Stig Hjarvard, \& Mette Mortensen (eds.), The Dynamics of Mediatized Conflicts (New York: Peter Lang, 2015), 51-69.

Miller, Daniel, et al., How the World Changed Social Media (London: UCL Press, 2016).

Norwegian National Research Ethics Committees, "Ethical Guidelines for Internet Research," National Committee for Research Ethics in the Social Sciences and the Humanities, December 2014. https://www.etikkom.no/en/ethical-guidelines-for -research/ethical-guidelines-for-internet-research/ (accessed 4 December 2015).

Pollack, Estr, "Personalized Scandalisation: Sensationalising Trivial Conflicts?," in: Mikkel Fugl Eskjær, Stig Hjarvard, \& Mette Mortensen (eds.), The Dynamics of Mediatized Conflicts (New York: Peter Lang, 2015), 93-110.

Postill, John, \& Sarah Pink, "Social Media Ethnography: The Digital Researcher in a Messy Web," Media International Australia 145/1 (2012), 123-134.

Skogerbø, Eli, \& Marte Winswold, "Nettet som debattarena [The Internet as a Platform for Debate]," in: Gunn Enli \& Eli Skogerbø (eds.), Digitale dilemmaer: Nye medieformer, nye utfordringer [Digital Dilemmas: New Types of Media, New Challenges] (Oslo: Gyldendal Akademisk, 2008), 39-59.

Slama, Martin, "Islamic (Inter)Faces of the Internet: Emerging Socialities and Forms of Piety in Indonesia," research project, 2014-2017. http://www.oeaw.ac.at/isa/ index.php?option=com_content\&view $=$ article $\&$ id $=392 \% 3$ Aislamic-interfaces-of -the-internet\&catid $=41 \% 3$ Asuedostasien-und-inselwelt-im-indischen-ozean $\&$ Itemid=65\&lang=de (accessed 11 May 2017).

Sumiala, Johanna, "Ritual Performance in Mediatized Conflict: The Death of a Princess and a Prime Minister," in: Mikkel Fugl Eskjær, Stig Hjarvard, \& Mette Mortensen (eds.), The Dynamics of Mediatized Conflicts (New York: Peter Lang, 2015), 111-128.

van Zoonen, Liesbet, Entertaining the Citizen: When Politics and Popular Culture Converge (Lanham: Rowman \& Littlefield, 2005). 